\title{
The Club Approach: A Gateway to Effective Climate Co-operation? - ERRATUM
}

Jon Hovi, Detlef F. Sprinz, Håkon Sælen and Arild Underdal

doi:10.1017/S0007123416000788, Published by Cambridge University Press, 15 June 2017.

The publisher apologises for an error in the key of Table 4. It currently reads:

Note: Vulnerability weight $=1$. Without conditional commitments.

But it should read:

Note: Vulnerability weight $=1$. With conditional commitments.

\section{Reference}

Hovi J, Sprinz DF, Sælen H and Underdal A (2017) The Club Approach: A Gateway to Effective Climate Co-operation? British Journal of Political Science 49, 1071-1096. doi:10.1017/S0007123416000788.

\footnotetext{
Cite this article: Hovi J, Sprinz DF, Sælen H, Underdal A (2020). The Club Approach: A Gateway to Effective Climate Co-operation? - ERRATUM. British Journal of Political Science 50, 809-809. https://doi.org/10.1017/S0007123419000425 